\title{
Buffer Solutions of Potassium Dihydrogen Phosphate and Sodium Succinate at $25^{\circ} \mathrm{C}$
}

\author{
Maya Paabo, Roger G. Bates, and Robert A. Robinson
}

(July 2, 1963)

\begin{abstract}
A buffer mixture consisting of equal molalities $(m)$ of potassium dihydrogen phosphate and sodium succinate is proposed as a useful reference point in the study of acid-base equilibria, bridging the present gap between $p \mathrm{H} 5.5$ and $p \mathrm{H} 6.8$. The $p\left(a_{\mathrm{H} \gamma \mathrm{Cl}}\right)$ at $25{ }^{\circ} \mathrm{C}$ has been determined by electromotive-force measurements for five buffer solutions in which $m$ varied from 0.005 to 0.025 . The conventional $p a_{\mathrm{H}}$ of each solution has been derived and found to be in good agreement with that calculated from existing data for the two equilibria concerned. The $p a_{\mathbf{H}}$ varies from 6.251 at $m=0.005$ to 6.109 at $m=0.025$. The buffer mixture has been used successfully for the determination of the dissociation constants of 2-nitro-4-chlorophenol and 2,6-dichlorophenol.
\end{abstract}

\section{Introduction}

The useful application of the acidity function - log $\left(a_{\mathrm{H}} \gamma_{\mathrm{Cl}}\right)$ or $p\left(a_{\mathrm{H}} \gamma_{\mathrm{Cl}}\right)$ in the accurate determination of dissociation constants or $p K$ values has been described $[1,2]{ }^{1} \quad$ In the determination of the $p K$ of a weak acid by the spectrophotometric method, a buffer solution is needed with a value of $p\left(a_{\mathrm{H}} \gamma_{\mathrm{Cl}}\right)$ not too far removed from the $p K$ of the acid. For example, in the determination of the dissociation constant of $p$-nitrophenol at $25{ }^{\circ} \mathrm{C}$ [3], $p K=7.156$, a series of equimolar mixtures of potassium dihydrogen phosphate and disodium hydrogen phosphate of different total ionic strengths were used; their $p\left(a_{\mathrm{H}} \gamma_{\mathrm{Cl}}\right)$ values lay between 6.912 and 7.080. For 2-chloro-4-nitrophenol, $p K=5.45$, solutions equimolal with respect to both sodium hydrogen succinate and sodium succinate were used [4]; their $p\left(a_{\mathrm{H}} \gamma_{\mathrm{Cl}}\right)$ values lay between 5.477 and 5.553.

Neither of these buffer systems would be particularly suitable for an acid with $p K$ about 6.2 and we have, therefore, now studied the buffer system consisting of sodium succinate and potassium dihydrogen phosphate at equal molalities $(m)$. The $p\left(a_{\mathrm{H}} \gamma_{\mathrm{Cl}}\right)$ values of five solutions in which $m$ varied from 0.005 to 0.025 have been determined at $25{ }^{\circ} \mathrm{C}$. Bv the application of a conventional definition of the activity coefficient of chloride ion, conventional $p a_{\mathrm{H}}$ values of these solutions have been calculated.

\section{Method}

The electromotive-force method by which $p\left(a_{\mathrm{H}} \gamma_{\mathrm{Cl}}\right)$ was determined and values of $p a_{\mathrm{H}}$ assigned has been thoroughly described in earlier publications [2, 5]. It consisted of the following three steps:

1. Measurement of the emf of the following cell:

Pt; $\mathrm{H}_{2}(\mathrm{~g}, 1 \mathrm{~atm}), \mathrm{KH}_{2} \mathrm{PO}_{4}(m), \mathrm{Na}_{2} \mathrm{C}_{4} \mathrm{H}_{4} \mathrm{O}_{4}(m), \mathrm{KCl}\left(m^{\prime}\right)$, $\mathrm{AgCl} ; \mathrm{Ag}$

${ }_{1}$ Figures in brackets indicate the literature references at the end of this paper. at $25^{\circ} \mathrm{C}$. Five different buffer mixtures consisting of equimolal amounts of potassium dihydrogen phosphate and sodium succinate ( $m$ varying from 0.005 to 0.025) were studied. Measurements were made with four concentrations $\left(\mathrm{m}^{\prime}\right)$ of potassium chloride, namely $0.005,0.01,0.015$, and 0.02 molal, at each of the five buffer concentrations.

The emf was corrected to a partial pressure of 1 atm hydrogen in the usual way, and $p\left(a_{\mathrm{H}} \gamma_{\mathrm{Cl}}\right)$ was calculated from each value of the emf $(E)$ by the formula

$$
p\left(a_{\mathrm{H}} \gamma_{\mathrm{C} 1}\right)=\frac{\left(E-E^{\circ}\right) F}{R T \ln 10}+\log m^{\prime}
$$

The standard potential $\left(E^{\circ}\right)$ was taken to be 0.22234 v at $25^{\circ} \mathrm{C}[6]$, and the coefficient $F /(R T \ln 10)$ has the value $16.9047 \mathrm{v}^{-1}$ at this temperature.

2. The limiting value of $p\left(a_{\mathrm{H}} \gamma_{\mathrm{Cl}}\right)$ in the absence of potassium chloride, tarmed $p\left(a_{\mathrm{H}} \gamma_{\mathrm{Cl}}\right)^{\circ}$, was determined for each of the five buffer solutions by plotting $p\left(a_{\mathrm{H}} \gamma_{\mathrm{Cl}}\right)$ as a function of the molality of added potassium chloride and extrapolating to 0 .

3. The conventional $p a_{\mathrm{H}}$ was computed from $p\left(a_{\mathrm{H}} \gamma_{\mathrm{Cl}}\right)^{\circ}$ by the relationship.

$$
p a_{\mathrm{H}}=p\left(a_{\mathrm{H}} \gamma_{\mathrm{Cl}}\right)^{\circ}+\log \gamma_{\mathrm{Cl}}
$$

with the use of the convention [7]

$$
\log \gamma_{\mathrm{Cl}}=\frac{-A \sqrt{I}}{1+1.5 \sqrt{I}}
$$

where $I$ is the ionic strength and $A$, the DebyeHückel slope, has the value 0.5108 mole $^{-1 / 2} \mathrm{~kg}^{1 / 2}$ at $25{ }^{\circ} \mathrm{C}$.

\section{Experimental Procedure}

The potassium dihydrogen phosphate was NBS Standard Sample 186 Ib. Two different samples of sodium succinate hexahydrate, reagent grade, were used. In addition, a portion of one of the samples 
was recrystallized and dried to remove its water of hydration. There were no apparent differences among buffers made from the three samples of sodium succinate. Potassium chloride was recrystallized once from water. The conductivity of the distilled water used to prepare the solutions was no greater than $0.8 \times 10^{-6} \mathrm{ohm}^{-1} \mathrm{~cm}^{-1}$.

An increase of emf with time, the cause of which has not been determined, was observed. This increase was more rapid with the dilute solutions than with the more concentrated ones. It was therefore found necessary to make the emf measurements on the three most dilute buffer mixtures on the same day the solutions were prepared. However, the same values of the emf were obtained for fresh $0.02 \mathrm{~m}$ and $0.025 \mathrm{~m}$ buffer solutions on the day of preparation and one day later.

In terms of $p a_{\mathrm{H}}$ units, the $0.025 \mathrm{~m}$ buffer solution increased in $p a_{\mathrm{H}}$ by only 0.002 after standing two days and 0.012 after 12 days. However, the $0.01 \mathrm{~m}$ solution increased by 0.012 unit in $24 \mathrm{hr}$ and the $0.005 \mathrm{~m}$ solution by 0.028 in the same time.

The stability of the primary and secondary phosphates in aqueous solution seems beyond question. Furthermore, no instability of buffer solutions composed of primary and secondary succinates was found in earlier work [8]. Nevertheless, it is advisable, for the greatest accuracy, to use the mixed buffers on the day of their preparation. This procedure was successful in the determination of the dissociation constants of 2-nitro-4-chlorophenol and 2,6-dichlorophenol (see below).

\section{Results and Discussion}

The results of the emf measurements and the calculations of $p\left(a_{\mathrm{H}} \gamma_{\mathrm{Cl}}\right)$ are summarized in table 1 . The average values of $p\left(a_{\mathrm{H}} \gamma_{\mathrm{Cl}}\right)$ corresponding to the four molalities of potassium chloride are plotted as a function of the chloride molality in figure 1 . The intercepts at $m^{\prime}=0$, that is $p\left(a_{\mathrm{H}} \gamma_{\mathrm{Cl}}\right)^{\circ}$, are given in table 2. The intercepts were determined by the method of least squares; the standard deviation of the intercept, $\sigma_{i}$, is given in the third column of the table. The $p a_{\mathrm{H}}$ values listed in the last column were calculated from $p\left(a_{\mathrm{H}} \gamma_{\mathrm{Cl}}\right)^{\circ}$ together with the conventional definition of the activity coefficient of chloride ion [see eqs (2) and (3)]. The $p a_{\mathrm{H}}$ of equimolal solutions of potassium dihydrogen phosphate and sodium succinate at $25^{\circ}$ is plotted in figure 2 as a function of the molality of each salt.

It is of interest to compare these experimental values of $p a_{\mathrm{H}}$ with the $p a_{\mathrm{H}}$ calculated from the dissociation constants for the two acid-base equilibria which fix the acidity of these buffer solutions. The dissociation constant of dihydrogen phosphate ion is given by $p K_{2 \mathrm{P}}=7.200$ at $25{ }^{\circ} \mathrm{C}$ [9], whereas that for succinate ion is expressed by $p K_{2 \mathrm{~S}}=5.636$ at the same temperature [8]. From the mass law expressions for the two equilibria,

$$
2 p a_{\mathrm{H}}=p K_{2 \mathrm{P}}+p K_{2 \mathrm{~S}}-\log \frac{m_{\mathrm{P}-} m_{\mathrm{S}^{-}}}{m_{\mathrm{P}=} m_{\mathrm{S}=}} \log \frac{\gamma_{\mathrm{P}-}}{\gamma_{\mathrm{P}=}}-\log \frac{\gamma_{\mathrm{S}-}}{\gamma_{\mathrm{S}=}}
$$

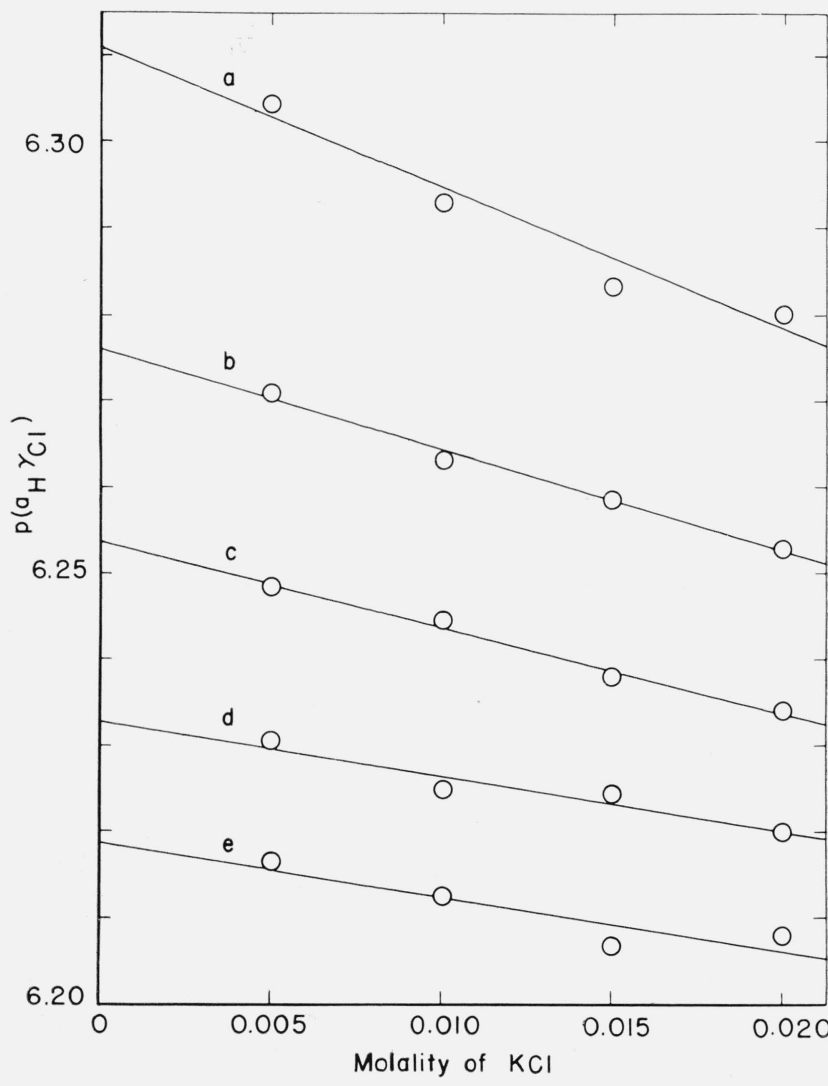

Figure 1. Effect of added potassium chloride on the p( $\left.a_{\mathrm{H} \gamma \mathrm{Cl}}\right)$ for equimolal mixtures of potassium dihydrogen phosphate and sodium succinate at $25^{\circ} \mathrm{C}$.

Molality of each buffer salt: a, $0.005 ; \mathrm{b}, 0.01 ; \mathrm{c}, 0.015$, d, 0.02; e, 0.025 .

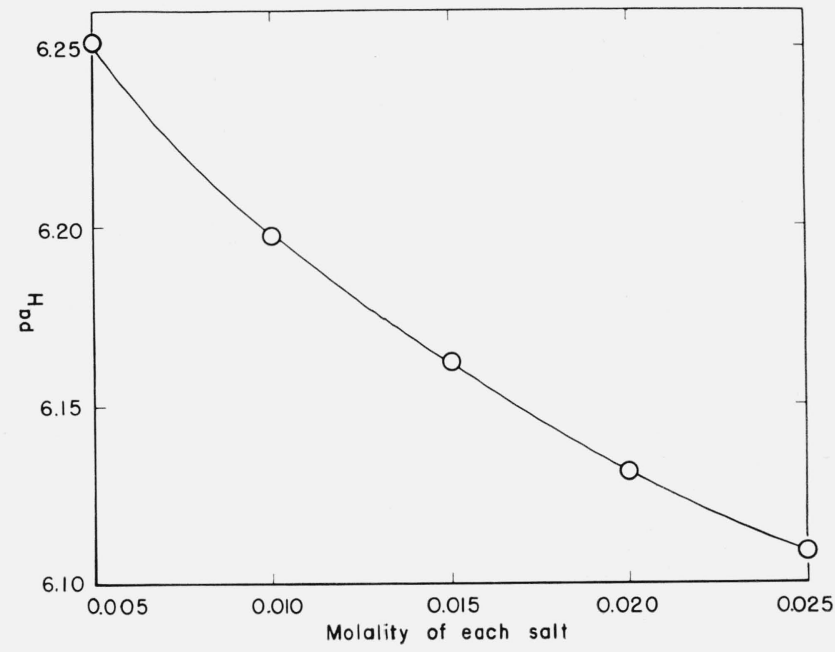

Figure 2. $\quad p a_{\mathrm{H}}$ at $25^{\circ} \mathrm{C}$ for equimolal mixtures of potassium dihydrogen phosphate and sodium sucoinate as a function of the molatity of each salt. 
TABLE 1. Electromotive force of the cell $\mathrm{Pt} ; \mathrm{H}_{2}(g, 1 \mathrm{~atm})$, $\mathrm{KH}_{2} \mathrm{PO}_{4}(m), \mathrm{Na}_{2} \mathrm{Suc}(m), \mathrm{KCl}\left(m^{\prime}\right), \mathrm{AgCl} ; \mathrm{Ag}$ at $25{ }^{\circ} \mathrm{C}$. Values of $p\left(a_{\mathrm{H}} \gamma_{\mathrm{Cl}}\right)$

\begin{tabular}{|c|c|c|c|c|c|c|c|c|}
\hline \multirow{3}{*}{$m$} & \multicolumn{8}{|c|}{$m^{\prime}$} \\
\hline & \multicolumn{2}{|c|}{0.005} & \multicolumn{2}{|c|}{0.010} & \multicolumn{2}{|c|}{0.015} & \multicolumn{2}{|c|}{0.020} \\
\hline & $E$ & $p\left(a_{\mathrm{H}} \gamma_{\mathrm{C} 1}\right)$ & $E$ & $p\left(a_{\mathrm{H}} \gamma_{\mathrm{C} 1}\right)$ & $E$ & $p\left(a_{\mathrm{H}} \gamma_{\mathrm{C} 1}\right)$ & $E$ & $p\left(a_{\mathrm{H}} \gamma_{\mathrm{Cl}}\right)$ \\
\hline 0.025 & $\begin{array}{r}0.72610 \\
.72627 \\
.72605 \\
.72636\end{array}$ & $\begin{array}{l}6.215 \\
6.218 \\
6.214 \\
6.219\end{array}$ & $\begin{array}{r}0.70815 \\
.70830 \\
.70806 \\
.70810 \\
.70808\end{array}$ & $\begin{array}{l}6.212 \\
6.215 \\
6.211 \\
6.212 \\
6.211\end{array}$ & $\begin{array}{r}0.69757 \\
.69751 \\
.69724 \\
.69723\end{array}$ & $\begin{array}{l}6.210 \\
6.209 \\
6.204 \\
6.204\end{array}$ & $\begin{array}{r}0.68990 \\
.69013 \\
.68999 \\
.69026\end{array}$ & $\begin{array}{l}6.205 \\
6.209 \\
6.206 \\
6.211\end{array}$ \\
\hline .020 & $\begin{array}{r}.72691 \\
.72706 \\
.72709\end{array}$ & $\begin{array}{l}6.229 \\
6.231 \\
6.232\end{array}$ & $\begin{array}{l}.70896 \\
.70879 \\
.70872 \\
.70904\end{array}$ & $\begin{array}{l}6.226 \\
6.223 \\
6.222 \\
6.228\end{array}$ & $\begin{array}{r}.69833 \\
.69835 \\
.69861\end{array}$ & $\begin{array}{l}6.223 \\
6.223 \\
6.227\end{array}$ & $\begin{array}{l}.69083 \\
.69098 \\
.69053\end{array}$ & $\begin{array}{l}6.221 \\
6.223 \\
6.216\end{array}$ \\
\hline .015 & .72808 & 6. 248 & .71005 & 6.245 & .69923 & 6. 238 & .69162 & 6.234 \\
\hline .010 & $\begin{array}{l}.72945 \\
.72936\end{array}$ & $\begin{array}{l}6.272 \\
6.270\end{array}$ & $\begin{array}{l}.71121 \\
.71108\end{array}$ & $\begin{array}{l}6.264 \\
6.262\end{array}$ & $\begin{array}{l}.70052 \\
.70039\end{array}$ & $\begin{array}{l}6.260 \\
6.257\end{array}$ & $\begin{array}{l}.69273 \\
.69272\end{array}$ & $\begin{array}{l}6.253 \\
6.253\end{array}$ \\
\hline .005 & $\begin{array}{l}.73136 \\
.73140\end{array}$ & $\begin{array}{l}\text { 6. } 304 \\
\text { 6. } 304\end{array}$ & $\begin{array}{r}.71298 \\
.71296 \\
.71279\end{array}$ & $\begin{array}{l}6.294 \\
6.294 \\
6.291\end{array}$ & $\begin{array}{l}.70191 \\
.70193\end{array}$ & $\begin{array}{l}6.283 \\
6.283\end{array}$ & $\begin{array}{l}.69430 \\
.69439\end{array}$ & $\begin{array}{l}6.279 \\
6.281\end{array}$ \\
\hline
\end{tabular}

TABLE 2. $p\left(a_{\left.\mathrm{H} \gamma_{\mathrm{C} 1}\right)^{\circ}}\right.$ and $p a_{\mathrm{H}}$ for equimolal solutions of potassium dihydrogen phosphate and sodium succinate at $25{ }^{\circ} \mathrm{C}$

\begin{tabular}{r|r|r|r}
\hline \hline$m$ & $p\left(a_{\mathrm{H}} \gamma_{\mathrm{Cl}}\right)^{\circ}$ & \multicolumn{1}{c|}{$\sigma_{i}$} & \multicolumn{1}{c}{$p a_{\mathrm{H}}$} \\
\cline { 1 - 1 } 0.025 & 6.219 & 0.001 & 6.109 \\
.020 & 6.233 & .001 & 6.131 \\
.015 & 6.254 & .001 & 6.162 \\
.010 & 6.276 & .001 & 6.197 \\
.005 & 6.311 & .002 & 6.251 \\
\hline
\end{tabular}

where $\mathrm{P}$ and $\mathrm{S}$ refer respectively to the phosphate and succinate ions of the indicated charge.

The acid-base reaction taking place when the two buffer salts are mixed in solution may be represented by

$$
\mathrm{H}_{2} \mathrm{PO}_{4}^{-}+\mathrm{Suc}^{-}=\mathrm{HPO}_{4}{ }^{-}+\mathrm{HSuc}^{-} .
$$

The extent to which this reaction proceeds need not be known, for the concentration term of eq (4) has a value of unity, provided the stoichiometric molalities of potassium dihydrogen phosphate and sodium succinate were equal. Furthermore, the ionic strength $(I)$ is equal to $4 \mathrm{~m}$ regardless of the extent to which reaction (5) proceeds.

The last two terms of eq (4) may be estimated as follows. In the course of the investigations which led to the determination of $p K_{2 \mathrm{P}}$ and $p K_{2 \mathrm{~S}}$ the quantities $\log \left[\gamma_{\mathrm{P}=} /\left(\gamma_{\mathrm{P}=} \gamma_{\mathrm{Cl}-}\right)\right]$ and $\log \left[\gamma_{\mathrm{S}=} /\left(\gamma_{\mathrm{S}-}\right.\right.$ $\left.\left.\gamma_{\mathrm{Cl}-}\right)\right]$ in phosphate buffer solutions and succinate buffer solutions, respectively, were evaluated and found to fit the Hückel equation with ion-size parameters of $4.4 \AA$ and $7.0 \AA$. If these same parameters are used to calculate the ratios of the activity coefficients of the two phosphate anions and of the two succinate anions in the mixed buffer at $25^{\circ}$, eq (4) then becomes

$$
p a_{\mathrm{H}}=1 / 2\left(p K_{2 \mathrm{P}}+p K_{2 \mathrm{~S}}\right)-\frac{1.532 \sqrt{m}}{1+2.89 \sqrt{m}}-\frac{1.532 \sqrt{m}}{1+4.60 \sqrt{m}} .
$$

The $p a_{\mathrm{H}}$ values calculated by this equation are compared in table 3 with those derived directly from the emf measurements. The agreement, which is most satisfactory, lends support to the reliability of the experimental data.

TABLE 3. "Observed" and calculated values of $p a_{\mathrm{H}}$ for five aqueous mixtures of $\mathrm{KH}_{2} \mathrm{PO}_{4}$ and $\mathrm{Na}_{2} \mathrm{C}_{4} \mathrm{H}_{4} \mathrm{O}_{4}$ at $25^{\circ} \mathrm{C}$

\begin{tabular}{r|r|r}
\hline \hline$m_{\mathrm{KH}_{2} \mathrm{PO}_{4}=m_{\mathrm{Na}_{2} \mathrm{Suc}}}$ & $p a_{\mathrm{H}}$ (observed) & $p a_{\mathrm{H}}($ calc., eq $(6))$ \\
\hline 0.025 & 6.109 & \\
.02 & 6.131 & 6.111 \\
.015 & 6.162 & 6.133 \\
.01 & 6.197 & 6.160 \\
.005 & 6.251 & 6.194 \\
& & 6.246
\end{tabular}

The change of $p a_{\mathrm{H}}$ with temperature can be calculated in a similar fashion. Inspection of eq (4) shows that the effect of temperature changes on the $p a_{\mathrm{H}}$ of the phosphate-succinate mixture will be a combination of the change of the mean $p K$ with temperature and of the temperature effect on the activity coefficients. The heats of dilution of completely dissociated electrolytes are neither large nor very different in the dilute range, and it is justifiable for our purpose to replace $d \log \left(\gamma_{\mathrm{P}=} / \gamma_{\mathrm{P}-}\right) / d T$ and $d \log \left(\gamma_{\mathrm{s}=} / \gamma_{\mathrm{s}-}\right) / d T$ by $3 d \log \gamma_{ \pm} / d T$, where $\gamma_{ \pm}$is the mean ionic activity coefficient of one of the common uni-univalent strong electrolytes and $T$ is the temperature in ${ }^{\circ} \mathrm{K}$. From eq (4), one may therefore write

$$
\frac{d}{d T} p a_{\mathrm{H}}=\frac{1}{2} \frac{d}{d T}\left(p K_{2 \mathrm{P}}+p K_{2 \mathrm{~S}}\right)-3 \frac{d}{d T} \log \gamma_{ \pm} .
$$

Data in the literature $[8,9]$ provide the following temperature coefficients:

$$
\frac{d p K_{2 \mathrm{P}}}{d T}=0.020912-\frac{2073.0}{T^{2}}
$$

and

$$
\frac{d p K_{2 \mathrm{~S}}}{d T}=0.019153-\frac{1679.13}{T^{2}}
$$

Furthermore, it has been shown that $d \log \gamma_{ \pm} / d \mathrm{~T}$ for four common strong electrolytes has the following average values at $25^{\circ}:-0.00007 \mathrm{deg}^{-1}$ at $I=0.01$, $-0.00012 \mathrm{deg}^{-1}$ at $I=0.04$, and $-0.0002 \mathrm{deg}^{-1}$ at $I=0.1$.

From these data it may be seen that the contribution of the changes in $p K$ to $d p a_{\mathrm{H}} / d T$ is -0.00180 $\mathrm{deg}^{-1}$ at $20{ }^{\circ} \mathrm{C},-0.00107 \mathrm{deg}^{-1}$ at $25{ }^{\circ} \mathrm{C}$, and $-0.00038 \mathrm{deg}^{-1}$ at $30{ }^{\circ} \mathrm{C}$. The temperature coefficient of $p a_{\mathrm{H}}$ at $25{ }^{\circ} \mathrm{C}$ for three of the mixed buffers is as follows:

$$
\begin{array}{cl}
m & d p a_{\mathrm{H}} / d T \\
0.005 & -0.00086 \mathrm{deg}^{-1} \\
.01 & -0.00071 \\
.025 & -0.0004
\end{array}
$$

It is clear that the phosphate-succinate mixture has 
a lower $p a_{\mathrm{H}}$-temperature coefficient than either the phosphate buffer or the succinate buffer at room temperature. This is a considerable advantage when the buffer is used in spectrophotometric measurements where the temperature of the absorption calls is not well controlled.

\section{Application to the Determination of Dissociation Constants}

To illustrate the use of these buffer solutions in spectrophotometric work and to obtain a further check on their $p\left(a_{\mathrm{H}} \gamma_{\mathrm{Cl}}\right)^{\circ}$ values, determinations of the dissociation constants of two substituted phenols is aqueous solution at $25^{\circ} \mathrm{C}$ have been made.

In the spectrophotometric method $[1,10]$, the dissociation constant $K$ of a weak uncharged acid $\mathrm{HA}$,

$$
K=\frac{a_{\mathrm{H}+} m_{\mathbf{A}^{-}}-}{m_{\mathrm{HA}}} \frac{\gamma_{\mathbf{A}^{-}}}{\gamma_{\mathrm{HA}}},
$$

is determined by measuring the degree of dissociation in a solution of known $p\left(a_{\mathrm{H}} \gamma_{\mathrm{Cl}}\right)^{\circ}$ by optical methods. Substitution of $\alpha$, the degree of dissociation, in eq (10) gives

$$
p K=p\left(a_{\mathrm{H}} \gamma_{\mathrm{Cl}}\right)^{\circ}-\log \frac{\alpha}{1-\alpha}-\log \frac{\gamma_{\mathrm{A}^{-}}}{\gamma_{\mathrm{Cl}^{-}-\gamma_{\mathrm{HA}}}} .
$$

A small correction is made to allow for the effect of the weak acid on $p\left(a_{\mathrm{H}} \gamma_{\mathrm{Cl}}\right)^{\circ}$ [11].

The succinate-phosphate buffer has been used to measure the dissociation constants of two substituted phenols. Details are given in tables 4 and 5. In the case of 2-nitro-4-chlorophenol (table 4), the last term of eq (11) has been neglected in arriving at $p K$ (corr.) The average of the five $p K$ values is $6.45_{8}$. Thare is a small but regular upward trend of $p K$ with decreasing ionic strengtb; this may indicate that the last term of eq (11) is not completely negligible, and extrapolation to zero ionic strength, by the method of least squares, gives $p K \quad 6.46_{5}$. Either value is in good agreement with that obtained earlier [4].

The value now found for 2,6-dichlorophenol, $6.78_{6}$, (table 5) is also in good agreement with $6.79_{1}$, which has been obtained in some unpublished work, using the potassium dihydrogen phosphate-disodium hydrogen phosphate buffer.
TABLE 4. Dissociation constant of 2-nitro-4-chlorophenol in

\begin{tabular}{|c|c|c|c|c|c|}
\hline $\begin{array}{c}\text { Ionic } \\
\text { strength a }\end{array}$ & $p\left(a_{\mathrm{H}} \gamma_{\mathrm{Cl}}\right)^{\circ}$ & $\mathrm{D}^{\mathrm{b}}$ & $\log \frac{D-D_{1}}{D_{2}-D}$ & $p K$ & $p K$ (corr.) \\
\hline $\begin{array}{l}0.10 \\
.08 \\
.06 \\
.04 \\
.02\end{array}$ & $\begin{array}{l}\text { 6. } 219 \\
\text { 6. } 233 \\
\text { 6. } 254 \\
\text { 6. } 276 \\
\text { 6. } 311\end{array}$ & $\begin{array}{r}0.356 \\
.359 \\
.366 \\
.374 \\
.384\end{array}$ & $\begin{array}{r}-0.230 \\
-.223 \\
-.206 \\
-.187 \\
-.165\end{array}$ & $\begin{array}{l}6.449 \\
6.456 \\
6.460 \\
6.463 \\
6.476\end{array}$ & $\begin{array}{l}6.448 \\
6.455 \\
6.458 \\
6.460 \\
6.469\end{array}$ \\
\hline & & & & $\stackrel{\mathrm{Av}}{K=}$ & $3 \times 10^{-7} 6.458$ \\
\hline
\end{tabular}
water at $25{ }^{\circ} \mathrm{C}$

a The molar concentration of 2-nitro-4-chlorophenol was $4.80 \times 10^{-5}$. The buffer solutions contained equimolar disodium succinate and potassium dihydrogen phosphate.

bThe absorption cells were $4 \mathrm{~cm}$ in length. $D_{1}$, the optical density of the undissociated phenol, measured in $0.01 \mathrm{M} \mathrm{HCl}$, was 0.062 . $D_{2}$, the optical density of the sociated phenol, measured in $0.01 M \mathrm{MCl}$, was 0.062 . $D_{2}$, the optical density of the
fully ionized phenol, measured in $0.01 \mathrm{M}$ NaOH, was 0.855 , Measurements were fully ionized phenol
made at $427 \mathrm{~m} \mu$.

TABLE 5. Dissociation constant of 2,6-dichlorophenol in

\begin{tabular}{|c|c|c|c|c|c|}
\hline $\begin{array}{c}\text { Ionic } \\
\text { strength a }\end{array}$ & $p\left(a_{\mathrm{H}} \gamma_{\mathrm{Cl}}\right)^{\circ}$ & $\mathrm{D}^{\mathrm{b}}$ & $\log \frac{D-D_{1}}{D_{2}-D}$ & $p K$ & $p K$ (corr.) \\
\hline $\begin{array}{r}0.10 \\
.08 \\
.06 \\
.04 \\
.02\end{array}$ & $\begin{array}{l}\text { 6. } 219 \\
\text { 6. } 233 \\
6.254 \\
\text { 6. } 276 \\
\text { 6. } 311\end{array}$ & $\begin{array}{r}0.365 \\
.376 \\
.389 \\
.409 \\
.431\end{array}$ & $\begin{array}{r}-0.572 \\
-.556 \\
-.537 \\
-.509 \\
-.478\end{array}$ & $\begin{array}{l}6.791 \\
6.789 \\
6.791 \\
6.785 \\
6.789\end{array}$ & $\begin{array}{l}6.790 \\
6.787 \\
6.789 \\
6.782 \\
6.783\end{array}$ \\
\hline \multicolumn{6}{|c|}{$\underset{K=1.64 \times 10^{-7}}{\operatorname{Avg}} 6.786$} \\
\hline
\end{tabular}
water at $25{ }^{\circ} \dot{C}$

aThe molar concentration of 2,6-dichlorophenol was $8.73 \times 10^{-5}$. The buffer solutions contained equimolar disodium succinate and potassium dihydrogen phosphate.

bThe absorption cells were $4 \mathrm{~cm}$ in length. $D_{1}$, the optical density of the undissociated phenol, measured in $0.01 \mathrm{MHCl}$, was $0 ., D_{2}$, the optical density of the fully ionized phenol, measured in $0.01 \mathrm{M} \mathrm{NaOH}$, was 1.728 . Measurements were made at $300 \mathrm{~m} \mu$

\section{References}

[1] R. G. Bates and G. Schwarzenbach, Helv. Chim. Acta 37, 1069 (1954).

[2] R. G. Bates and R. Gary, J. Res. NBS 65A, 495 (1961).

[3] G. F. Allen, R. A. Robinson, and V. E. Bower, J. Phys. Chem. 66, 171 (1962).

[4] V. E. Bower and R. A. Robinson, J. Phys. Chem. 64, $1078(1960)$

[5] R. G. Bates, J. Res. NBS $\mathbf{6 6 \mathbf { A } ,} 179$ (1962).

[6] R. G. Bates and V. E. Bower, J. Res. NBS 53, 283 (1954).

[7] R. G. Bates and E. A. Guggenheim, Pure and Appl. Chem. 1, 163 (1960).

[8] G. D. Pinching and R. G. Bates, J. Res. NBS 45, 322 (1950) RP 2142

[9] R. G. Bates and S. F. Acree J. Res. NBS 34, 373 (1945); A. K. Grzybowski, J. Phys. Chem. 62, 555 (1958).

[10] R. A. Robinson and A. I. Biggs, Trans. Faraday Soc. 51, 901 (1955).

[11] R. A. Robinson and A. K. Kiang, Trans. Faraday Soc. 51, 1938 (1955).

(Paper 67A6-242) 